\title{
EXPLORING THE EFFECT OF CUSTOMER ORIENTATION ON DANA INSURANCE PERFORMANCE CONSIDERING THE INTERMEDIARY ROLE OF CUSTOMER RELATIONS AND SERVICE QUALITY MANAGEMENT
}

\section{Mahrokh Mokhtaran ${ }^{11}$, Bahareh Komeilian ${ }^{12}$}

\begin{abstract}
The aim of the present research was to explore the effect of customer orientation on Dana Insurance Company's performance with a focus on the intermediary role of managing customer relations and services quality. To this end, 180 Dana insurance representatives in Tehran, Iran were randomly sampled. As an applied study in terms of its goal, this research is carried out in a cross-sectional descriptive-survey design. The information was collected through literature review and a questionnaire with 55 items which was validated through expert panel. The reliability of the questionnaire was approved at 0.986 probability level as calculated using Cronbach's Alpha measure. Data analysis was performed at two descriptive and interpretative statistical levels using SPSS software program. The results from regression analysis indicated that customer orientation of Dana insurance company has a significant positive effect on marketing performance, financial performance, and organizational performance. In addition, customer orientation has a significant positive effect on Dana Insurance company's customer relationship management and service quality.
\end{abstract}

KEY WORDS: customer orientation; customer relations management; marketing performance; financial performance

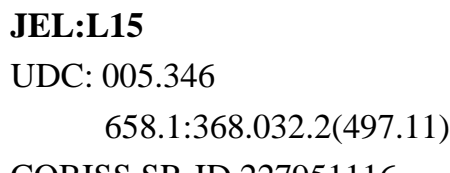

COBISS.SR-ID 227951116

\footnotetext{
${ }^{11}$ Corresponding author, Firoozkooh Branch, Islamic Azad University, Tehran, Iran, e-mail: m.mokhtaran@iaufb.ac.ir

${ }^{12}$ Firoozkooh Branch, Islamic Azad University, Tehran, Iran
} 


\section{INTRODUCTION}

Customer relationship management is the continued process of new value identification and creation with each customer and then sharing the benefits of this value throughout the lifecycle of a firm. This issue requires cognition, concentration and management of incessant collaboration between producers and the selected customers in order to reciprocally produce and share value through interdependencies and organizational arrangements. Since business sphere is now founded on customer orientation and satisfaction, operators in the economic field and those who think of eternal survival within the field, well recognize that the breathing air in the business world is customer orientation mantra (Momeni et al., 2013).

Having a mutually beneficial long-term relationship with customer, has long been the goal of the majority of firms. Among the advantages of such a relationship is increased customer honesty and satisfaction among customer. High levels of customer loyalty and satisfaction can result in sales and profits to increase. As vendors are the exterior or the frontline of organizations, they are encouraged to adopt customer-oriented behavior (Saadati, 2012).

Today, customer orientation is considered a basis for the onward movement and survival in firms operating in competitive markets. In other words, all the paths to survival and profitability of an organization and enterprise will lead to preserving and promoting customer loyalty and assuring them as to their access to the their expected services in the shortest possible time span and with the best possible quality (Barkur et al., 2007).

Delivering quality services plays a crucial role in service industries such as insurance, welfare etc. as service quality is vital to the survival and profitability of these organizations and a means of superiority over competitors is to continuously deliver comparatively higher service quality than do the competitors (Kassim,Abdullah, 2010). Service quality as a crucial factor that determines the success of service organizations in today's competitive environment has received great attention. Any reduction in customer satisfaction level due to low quality of services is the cause of many concerns for service organizations (Haj Karimi et al., 2009).

What at present is of paramount importance to insurance companies in the current markets is the retention of the existing portfolio and adopting a new one, a significant issue which is directly correlated with customer loyalty. Insurance firm representatives and agents as one of the most important distribution channels for insurance services, play an important part in customer satisfaction and loyalty. Seen from this perspective, selecting a customer orientation strategy on the part of the representatives in insurance industry and the impact of the adopted strategy on organizational performance is of great importance. Dana insurance company, the third largest firm in Iran's insurance services market has secured 5.6 percent of the market. This company has been distinguishing its services from early on in standardizing operations through obtaining certifications for risk management, customer orientation, and services quality. Therefore, given the key role played by Dana insurance company in Iranian insurance industry, the authors set out to investigate the effect of customer orientation on the financial and marketing performance of this company in the present study. 


\section{LITERATURE REVIEW}

An extremely critical challenge confronted by today's organizations is customer orientation, and to gain their customers' satisfaction which enables the organization to survive in the world of competition (Kordnaeij, 2005). Customer orientation, an important issue generally for all firms and particularly for service providing firm, is a conception which places customer in the focus thus not excluding customer from other stakeholders (Kim et al., 2010).

Being customer-oriented implies that an organization is actively seeking to create, proliferate, and respond to market information, but also refers to employees' capacity for relating to customers, which in turn, has a positive effect on customer satisfaction. Customer-oriented organizations predict new customer needs and respond to those needs by delivering goods and services which are of higher value and generate customer satisfaction (Brady,Gronin, 2001). In addition, customer-oriented behavior can build a good relationship between service provider and customers and subsequently bring in enhanced organization performance (Brown et al., 2002).

One customer-oriented organizational model is Customer Relationship Management (CRM) which uses customer information to create a customized strategy so as to increase customer loyalty level while reducing operational costs (Wan, Luk, 2005). Customer Relationship Management (CRM) is a managerial strategy which helps organizations gather, analyze, and manage information on customers through information technology (IT) tools in order to meet customer needs and build a mutually profitable long-term relationship (Hung et al., 2010). CRM is a type of marketing strategy which is not aimed merely at temporary increases in profits, but it causes customer satisfaction and profits to increase in the long run and consequently organizational performance to improve (Stefanou et al., 2003).

Organizational performance is one the crucial constructs discussed in management research. If organizational performance consistently remains at a lower level than customers expect, they will simply change their backs to the organization causing it to eventually fail. Therefore, firms with higher levels of organizational performance are stronger invariably and more successful in the long turn (Rezayi-Kohan, 2007). Organizational performance is measured through financial and marketing performance: financial measures are among the essential components of performance evaluation systems. Particularly, in for-profit organizations measures of this perspective specify what financial results and outcomes will the successful implementation of the goals set in the other two perspectives ultimately lead to. Organizations can dedicate all their efforts to improving customers' satisfaction, quality improvement, and reducing products and services delivery times. However, if these actions do not result in tangible outcomes in the organization financial reports and statements, they will not be of much value (Kaplan, Norton, 2004).

Measuring marketing performance as one of the key marketing issues, plays a significant role in responding to the increasing competitive pressures in today's markets and can have a considerable effect on promoting the role of marketers in aligning an organization's overall strategies. In defining marketing performance it can be noted that marketing performance refers the ability of an organization to increase sales, improve firm competitive position, develop new products, reduce products or services delivery times, improve products or services quality, expand markets etc. compared to other competitors in a specific industry (Noori, 1391).

With respect to services, quality is considered as one of the most important evaluation criteria; a wide concept to which various departments of an organization are committed. 
The goal of quality is to improve overall organizational performance at minimum costs in order to increase competitiveness, in a way that that it adapts the entire organization to the characteristics expected by the customers. Services quality encompasses three dimensions: the physical, situational and behavioral. In other words, services quality is focusing on what is delivered to customers, the situation in which the services are offered, and how they are delivered (Ross et al., 2003). In service providing organizations services quality is vital. Indeed, the most significant indicator of external effectiveness for service organizations is services quality (Cutler,Armstrong, 1385).

The significance of services quality is visible in the ability of an organization or firm to meet customers' needs and demands. Firms can make profits by achieving competitive advantage through offering the best practices of preserving services quality which can in turn lead to customer satisfaction and organizational performance improvement (Hussain et al., 2014).

\section{EMPIRICAL BACKGROUND}

Mohsenian et al. (2014) published a paper titled "Investigating the effect of customer relationships management on Citizens' satisfaction in Mashhad Municipal Regions through the intermediary role of managerial innovation in Islamic Iranian City model." The pusporse of their research was to investigate the effect of customer relationship management (CRM) on customers' satisfaction through the intermediary role of innovation among the citizens referring to Mashad municipality offices and employees. The measurement instrument in the research is a questionnaire consisting of two categories of items. The first comprises the questionnaire regarding customer satisfaction evaluation with respect to Mashhad municipality with 11 items and the other a questionnaire consisting of 12 items on innovation and customer relationship management (15 items) and consists of 27 items. To analyze the data, structural equations modelling and the least partial squares are used. The results of analyzing the data from the distributed questionnaires in a sample of 182 municipality employees and 265 referees to Mashhad municipality was carried out in PLS program demonstrated that only the correlation between customer relationship management and satisfaction is valid and significant and other correlations including that between customer relationship management and satisfaction, between innovation and satisfaction and the intermediary effect of innovation between customer relationships management and customer satisfaction do no hold.

Momeni (2013) presented a paper titled "Investigating factors influencing Customer relationship management (CRM) Success in Melli Bank Tehran Branches." The purpose of his study was to investigate the factors that influence the success of customer relationship management in Melli bank. The results of data analysis using LISREL program indicates the effect of knowledge management, customer orientation, marketing capability, and CRM technology on the success of CRM.

Abdul Alem et al. (2013) have carried out a research titled "Evaluating the effect of customer relationship management (CRM) on organizational performance dimensions in Malaysian hospitality industry." The goal of their research was to investigate the correlation between CRM dimensions, e.g. CRM and customer orientation, knowledge management and technology-based CRM, and various aspects of organizational performance e.g. financial, customer, internal processes, training and growth in Malaysian hotels. The research was a quantitative study of 152 Malaysian hotel managers of hotels ranging from 3 -star to 5-star. The results from this study show that all the correlations among customer 
relationship management are positive with a considerable effect on the various hotel performance perspectives under study.

Soch and Sandhu (2008) carried out a research titled "Does Customer Relationship Management Influence Organization Performance" with the aim to identify the effect of customer relationship management (CRM) on firm financial performance in India. The study identified four customer relationship constructs namely, sensitivity to customer needs, communications, intermediaries, and firm internal environment. The measurement scale was developed, redefined and evaluated using confirmative factorial analysis (CFA) to confirm the model fitness. The firm information on growth and profitability were used as the estimation indices in the regression model. The results of this research which used a relatively large sample consisting of 171 firms in 8 different industries, shows that customers relationship management (CRM) has a positive effect on firm performance; however, the strength of the effect was not high.

Based on the reviewed literature and having explored several frameworks presented in areas relevant to the subject at hand under this study, the conceptual model used by Jeong et al. (2014) is adopted as the basis of the present study. The model covers all the variables and correlations that this study intends to assess.

Based on the conceptual model, the hypotheses of the research hypotheses are as follows:

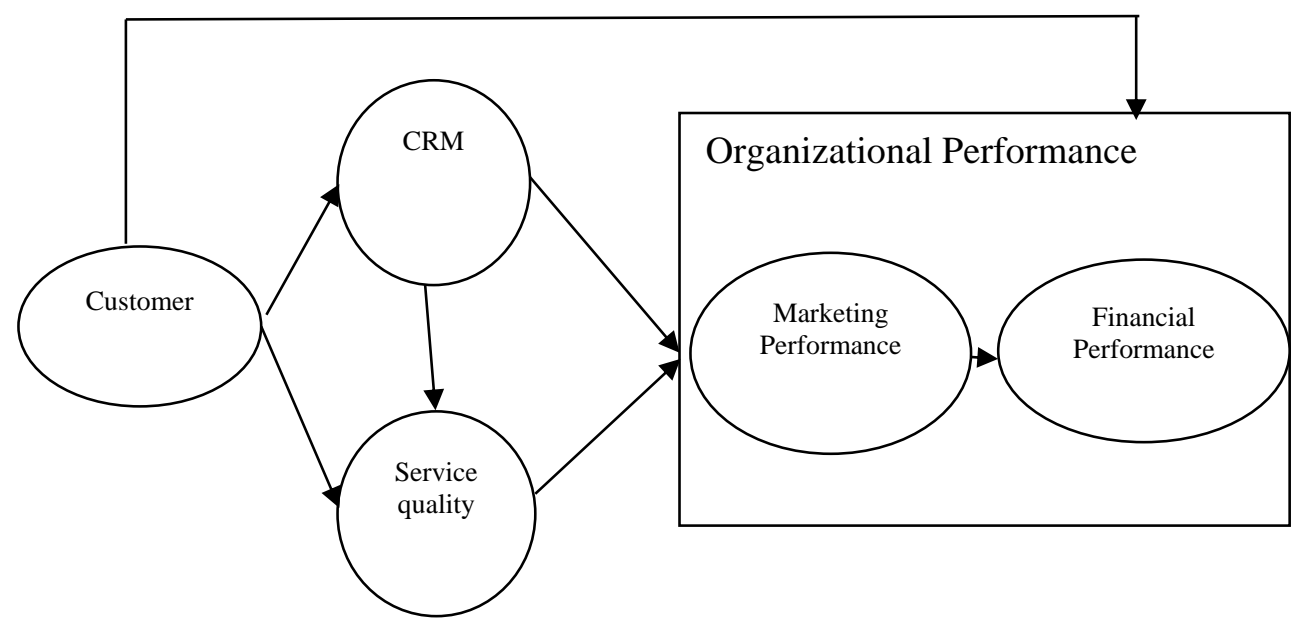

Source:Jeong et al.,2014

\section{Major Hypotheses:}

1. Customer orientation has significant positive effect on firm performance.

2. Customer orientation has a significant positive effect on firm financial performance.

3. Customer orientation has a significant positive effect on firm marketing performance. 


\section{Minor Hypotheses}

1. Customer orientation has significant positive effect on customer relationship management.

2. Customer orientation has a significant positive effect on services quality.

3. Customer relationship management has significant positive effect on services quality.

4. Customer relationship management has a significant positive effect on marketing performance.

5. Services quality has a significant positive effect on marketing performance.

6. Marketing performance has a significant positive effect on firm financial performance.

\section{METHODOLOGY}

The present research has an empirical and applied nature in terms of its purpose and in terms of data collection and procedure is carried out in a cross-sectional survey-based descriptive design. To carry out this study, given the research goals, having completed a literature review, a 55-item questionnaire covering 5 dimensions namely, customer orientation, customer relationship management (CRM), services quality, marketing performance, financial performance, based on a 5-point Likert scale was designed. The questionnaire content validity and further necessary modifications were conformed and made through an expert panel consisting of academics, experts and informants on the research subject. In order to assess the reliability of the questionnaire, a Cronbach's Alpha was used. To this end, first 30 questionnaires were distributed among experts and academics and were collected upon completion and the Cronbach's Alpha value was calculated to be 0.98 . Thus the questionnaire was of high reliability. Once the validity and reliability of the data collection instrument were established, in a field work the questionnaire was presented to the sample members of the population. The population for this research consisted of 334 Dana insurance agents in Tehran, Iran. Based on the Cochran's formula, 180 individuals were randomly selected as the sample. After collecting the filled questionnaires, the data were analyzed using Kolmogorov-Smirnoff and regression tests and the results were reported.

\section{Research Findings}

\section{Demographics}

An analysis of the demographics from this research revealed that the majority of respondents were female, married, relatively young employees within 30 to 45 age range. The respondents' education was at bachelor level who had worked for 10 to 15 years in Dana insurance company. 
Table 1: Respondents' Demographics (in percentage)

\begin{tabular}{|c|c|c|c|c|c|c|c|c|c|c|}
\hline \multicolumn{3}{|c|}{ Sex } & \multicolumn{3}{|c|}{ Marital Status } & \multicolumn{5}{|c|}{ Age (years) } \\
\hline Female & \multicolumn{2}{|c|}{ Male } & \multicolumn{2}{|c|}{ Single } & Married & $<30$ & & $30-45$ & $>$ & \\
\hline 57.2 & \multicolumn{2}{|r|}{42.8} & \multicolumn{2}{|c|}{33.3} & 66.7 & 28.3 & & 52.2 & & \\
\hline \multicolumn{6}{|c|}{ Education } & \multicolumn{5}{|c|}{ Work Experience (years) } \\
\hline $\begin{array}{c}\text { High } \\
\text { school }\end{array}$ & Diploma & $\begin{array}{c}\text { College } \\
\text { Undergraduate }\end{array}$ & Bachelor & Master & $\mathrm{PhD}$ & $<5$ & $\begin{array}{l}5- \\
10\end{array}$ & $\begin{array}{c}10- \\
15\end{array}$ & $\begin{array}{l}15- \\
20\end{array}$ & $>20$ \\
\hline 0 & 1.2 & 10.3 & 43.7 & 36.8 & .8 & 9.1 & 22.3 & 39.7 & 16.2 & 12.7 \\
\hline
\end{tabular}

\section{Hypotheses Testing Through Regression Analysis}

In this research, linear regression analysis was used to test and confirm/reject the hypotheses and draw conclusions. Using a simple linear regression every hypothesis and hypothesized correlations in the research were independently taken and tested. In each regression correlation there is only one factor, one influencing independent variable against the dependent variable. The table below represents the results of the regression analyses:

Table 2: Linear regression analysis: test results

\begin{tabular}{|c|c|c|c|c|c|c|}
\hline \# & $\begin{array}{c}\text { Independent } \\
\text { Variable }\end{array}$ & $\begin{array}{c}\text { Dependent } \\
\text { Variable }\end{array}$ & $\begin{array}{c}\text { T } \\
\text { Value }\end{array}$ & $\begin{array}{c}\text { Correlation } \\
\text { Coefficient }\end{array}$ & $\begin{array}{c}\text { Significance } \\
\text { Level }\end{array}$ & $\begin{array}{l}\text { Hypothesis } \\
\text { testing result }\end{array}$ \\
\hline \multicolumn{7}{|c|}{ Major Hypotheses } \\
\hline 1 & $\begin{array}{c}\text { Customer } \\
\text { Orientation }\end{array}$ & Firm Performance & 16.52 & 0.778 & 0.000 & Confirmed \\
\hline 2 & $\begin{array}{c}\text { Customer } \\
\text { Orientation }\end{array}$ & $\begin{array}{c}\text { Financial } \\
\text { Performance }\end{array}$ & 13.94 & 0.723 & 0.000 & Confirmed \\
\hline 3 & $\begin{array}{c}\text { Customer } \\
\text { Orientation }\end{array}$ & $\begin{array}{c}\text { Marketing } \\
\text { Performance }\end{array}$ & 16.073 & 0.769 & 0.000 & Confirmed \\
\hline \multicolumn{7}{|c|}{ Minor Hypotheses } \\
\hline 1 & $\begin{array}{l}\text { Customer } \\
\text { Orientation }\end{array}$ & $\begin{array}{c}\text { Customer } \\
\text { Relationship } \\
\text { management }\end{array}$ & 9.629 & 0.585 & 0.000 & Confirmed \\
\hline 2 & $\begin{array}{l}\text { Customer } \\
\text { Orientation }\end{array}$ & Services Quality & 13.249 & 0.705 & 0.000 & Confirmed \\
\hline 3 & $\begin{array}{c}\text { Customer } \\
\text { Relationship } \\
\text { management }\end{array}$ & Services Quality & 26.563 & 0.894 & 0.000 & Confirmed \\
\hline 4 & $\begin{array}{c}\text { Customer } \\
\text { Relationship } \\
\text { management }\end{array}$ & $\begin{array}{c}\text { Marketing } \\
\text { Performance }\end{array}$ & 19.673 & 0.828 & 0.000 & Confirmed \\
\hline 5 & Services Quality & $\begin{array}{c}\text { Marketing } \\
\text { Performance }\end{array}$ & 32.095 & 0.923 & 0.000 & Confirmed \\
\hline 6 & $\begin{array}{c}\text { Marketing } \\
\text { Performance }\end{array}$ & $\begin{array}{c}\text { Financial } \\
\text { Performance }\end{array}$ & 21.432 & 0.849 & 0.000 & Confirmed \\
\hline
\end{tabular}




\section{Interpretation: Testing Major Hypotheses}

Customer orientation in Dana insurance company has a significant, positive and direct effect on marketing performance, financial performance, and overall organizational performance. This indicates that the efforts of Dana insurance company towards promoting customer orientation have a positive effect on marketing performance, financial performance, and organizational performance independently. Further, in Dana insurance company per single-unit increase in customer orientation, organizational performance, financial performance, and marketing performance of the company independently improve $0.778,0.723,0.769$ units, respectively. These correlations, when considered independently, of the two variables financial performance and marketing performance, marketing performance with a larger correlation coefficient, is influenced by the customer orientation efforts of Dana insurance company more than is financial performance.

\section{Interpretation: Testing Minor hypotheses}

Customer orientation in Dana insurance company has a significant and positive effect on customer relationship management as well as on the quality of the services offered to the customers of the company. As a result, the efforts made by Dana insurance company towards customer orientation, when the correlations are considered separately, contributes to the enhancement of customer relationship management (CRM) and quality improvement of the services offered to the customers. In addition, for a one-unit increase in customer orientation in Dana insurance company, customer relationship management and the quality of services offered to customers independently increase by 0.705 and 0.585 units respectively. When the correlations are considered independently, the quality of services offered by Dana Company, with a larger correlation coefficient than customer relationship management $(\mathrm{CRM})$, receive a greater effect by customer orientation improvement.

Customer relationship management (CRM) in Dana insurance company as a factor affecting the quality of the service offered to the customers as well as marketing performance of the company. For every unit of increase in the company's effort towards improving customer relationship management, services quality and marketing performance independently increase by 0.894 and 0.828 units, respectively. When considered separately, the quality of the services that the company offers its customers with a correlation coefficient larger than that of marketing performance, is affected more by customer relationship management (CRM). As a result, the efforts by Dana insurance company towards improving customer relationship management significantly and directly influences services quality and marketing performance of the company also when the correlations are considered independent of each other.

The quality of the services offered to the customers has a positive and direct effect on marketing performance and the company's efforts towards improving the quality of the services results in the enhanced marketing performance of this company. For a one-unit increase in services quality a corresponding increase by 0.923 units occurs in the marketing performance.

Finally, the marketing performance of the company also has a positive effect on financial performance as its increase by one unit is corresponding to 0.849 unit improvements in the financial performance. 


\section{Conclusions and Further Research Suggestions}

The results of the regression analysis indicated that customer orientation has a positive and significant effect on the organizational performance. The support for this hypothesis is also consistent with the results reported in studies by Appiash, Singh (1998) and Smirnov (2011). Furthermore, the positive and significant effect of customer orientation on financial and marketing performances was also supported by this research. This hypothesis has also been supported by Muria et al. (2015) and Miraghayi et al. (1292). In addition, based on the data analysis results it was revealed that customer orientation has positive significant effect on services quality in line with Jeong et al. (2014). Upon the confirmation of the hypotheses the following suggestion are made:

- A control system should be considered to analyze and solve customers' problems.

- Research and development (R\&D) cycle time should be continuously reduced.

- Insurance systems integrations should be performed based on the Internet and in a modern manner.

- The information and feedback from customer should be used in product development process.

- Sufficient resources and facilities to meet customers' need should be made available to employees and insurance policies should be delivered at no charge to the policy holders by curriers familiar with insurance affairs and equipped with mobile P.O.S to make policy fee payments.

Another result from data analysis is that customer relationship management (CRM) has a significant positive effect on services quality and marketing performance as corroborated by the results in Soch and Sundhu (2008) and Momtazi and Rahimi (1292). On this basis it is suggested that:

- Matches are made between the number of the responding personnel and that of the referees to avoid the referees' time being wasted and thus their dissatisfaction.

- Employees should be trained on what the necessity for buying insurance policies is so as to enable them provide the public with useful information on various types of policies as well as their benefits, so that insurance products come to be considered a necessity in people's life changing people's attitude to shape insurance-receptive behavior.

- Customers should be the focus of attention and eliciting customer satisfaction should be a major goal of organizations. In this direction, adopting motivational instruments such as allocating larger discount rates and premium facilities for loyal customers can be effective.

The positive effect of services quality on marketing performance and that of marketing performance in financial performance were also confirmed, a finding consistent with Jeong et al. (2014) and Pesian (1391). In view of these hypotheses being confirmed, the following suggestions are made:

- Employees should be trained to become more oriented towards customers and build good relationships in their encounters with customers. 
- Proper guidance and advice to employees in making the right choice is one expectation that influences customer satisfaction. A specific location should be predicted for the referees with air conditioning system, cleanliness, pleasant scent, aesthetic and appealing environment also contribute to customer attraction.

- Employees with sufficient knowledge should be used to answer customers' enquiries and questions. Proper guidance and fast paced service delivery is considered important by customers who are not aware of organizational workflow and who don't know the rules.

It is also suggested to scholars to carry out a similar study in other insurance companies and to compare their results with the present research. Future research can evaluate the effect of customer orientation in marketing performance and financial performance in other industries. It is also suggested a study to replicate the present research in Dana insurance branches in other cities and compare the results with the present study. This study was carried out in Tehran which has different conditions from other cities due to various reasons. Replicating this study in other provinces would certainly contribute to the reliability of the results yielded in this study.

\section{REFERENCES}

[1] Abbaszadegan, M. (2015). Performance Management. Tehran: Sahami Enteshar CO.

[2] Abdul alem, M., Basri bin, R.,Shaharuddin bin, T. (2013). Assessing the influence of customer relationship management (CRM) dimensions on organization performance: An emperical study in the hotel industry. Journal of Hospitality and Tourism Technology, 4(3): $228-247$.

[3] Barkur, G. Varambally, K.V.M., Rodrigues, L.L.R. (2007). Insurance Sector Dynamics: Towards Transformation into Learning Organization. The Learning Organization, 14 (6):510-523.

[4] Brady, M.K.,Gronin, Jr. J. (2001). Customer Orientation: Effects on Customer Service Perceptions and Outcome Behavior`s. Journalof Service Research, 3(3): 78-92.

[5] Brown, T. J., Mowen, J. C., Donavan, D. T.,Licata, J. W. (2002). The customer orientation of service workers: Personality trait effects on self-and supervisor performance ratings. Journal of Marketing Research, 39(1), 110-119. Innovation Process.

[6] Hajikarimi, A., Malekizadeh, V., Jamalie Bastami, B. (2009). Exploring Correlation between Service Encounter Quality and Customers' Loyalty in Commercial Service Organizations. Management Vision, (32): 29-47.

[7] Hung, S. Y., Hung, W. H., Tsai, C. A.,Jiang, S. C. (2010). Critical factors of hospital adoption on CRM system: organizational and information system perspectives, Decision Support System Journal 48: 592-603.

[8] Hussain, R., Al Nasser, A.,Hussain, Y. (2014). Service quality and customer satisfaction of a UAE-based airline: An empirical investigation. Journal of Air Transport Management, 1-9.

[9] Jeong, D., Kim, S.,Yoon, D. (2014). Customer Orientation and Organizational Performance: Mediating Role of CRM. Advanced Science and Technology Letters, 57: 35-39. 
[10] Kaplan, R.s.,Norton, d.p. (1996). Using the balanced scorecard as a strategic management system. . journal : harvard business review.

[11] Kassim, N.,Abdullah, N. A. (2010). The effect of perceived service quality dimensions on customer satisfaction, trust, and loyalty in e-commerce settings. Asia Pacific Journal of Marketing and Logistics, 22(3): 351-371.

[12] Kim, H., Young-Gul, K., Chan-Wook, P. (2010). Integration of firm's resource and capability to implement enterprise CRM: A case study of a retail bank in Korea. Decision Support Systems, 48:313-322.

[13] Kordnayij, A. (2005). Customer Orientation: Success Key of Excellent Organizations. Management Studies, Iranian Center for Management and productivity Studies (153): 43-44.

[14] Kotler, Ph.,Armstrong, G. (2012). Principles of Marketing.

[15] Mohsenian, M., khorakian, A.,Maharati, Y. (2014). Investigating the effect of customer relationships management on Citizens' satisfaction in Mashhad Municipal Regions through the intermediary role of managerial innovation in Islamic Iranian City model. 6th National Conference on Urban Planning and Management with Emphasis on the Elements of Islamic City, 1-30.

[16] Momeni, M., kheyri, B.,Hasani, M. (2013). Investigating factors influencing Customer relationship management (CRM) Success in Melli Bank Tehran Branches. Marketingarticle. 1-17.

[17] Rezayi-kohan, S. (2007). Investigating Customers' Services Quality Expectations of Women Physical Readiness Centers in Mashhad City. M.A. Thesis, Tehran: Tehran University.

[18] Saadati, P. (2012). The Effect of Customer Orientation and Sales Centeredness on Agents' Sales Performance: the Cases of Moallem and Kawthar Insurance Companis. M.A. thesis in Business Management Insurance Specialty, Tehran: Allameh Tabatabayi Unniversity.

[19] Soch, H.,Sandhu H.S. (2008). Does Customer relationship management activity affect firm performance. Global Business Review, 9(2): 189- 206.

[20] Stefanou, C., Sarmaniotis, C.,Stafyla, A. (2003). CRM and customer-centric knowledge management: an empirical research. Journal of Business Process Management, 9(5): 617-34.

[21] Wan, W., Luk, C., Chow, C. (2005). Customers' adoption of banking channels in Hong Kong. International Journal of Bank Marketing, 23(3): 255-72.

\section{Article history:}

- $\quad$ Received 19 October 2016

- $\quad$ Accepted 29 November 2016 